\title{
Five years post whiplash injury: Symptoms and psychological factors in recovered versus non-recovered
}

\author{
Daniel Merrick and Britt-Marie Stålnacke*
}

\begin{abstract}
Background: Few studies have focused on the differences between persons who are recovered after whiplash injury and those who suffer from persistent disability. The primary aim of this study was therefore to examine differences in symptoms, psychological factors and life satisfaction between subjects classified as recovered and those with persistent disability five years after whiplash injury based on the Neck Disability Index (NDI).

Methods: A set of questionnaires was answered by 158 persons ( 75 men, 83 women) to assess disability (NDI), pain intensity (VAS), whiplash-related symptoms (Rivermead Post-Concussion Symptoms Questionnaire, RPQ), posttraumatic stress (Impact of Event Scale, IES), depression (Beck's depression inventory, BDI) and life satisfaction (LiSat-11). The participants were divided into three groups based on the results of the NDI: recovered (34.8\%), mild disability (37.3\%) and moderate/severe disability (27.3\%).

Results: The moderate/severe group reported significantly higher VAS, BDI and IES scores and lower level of physical health and psychological health compared to the mild and the recovered groups. Less significant differences were reported between the mild and the recovered groups.

Conclusions: The group with the highest disability score reported most health problems with pain, symptoms, depression, post-traumatic stress and decreased life satisfaction. These findings indicate that classifying these subjects into subgroups based on disability levels makes it possible to optimize the management and treatment after whiplash injury.
\end{abstract}

\section{Background}

The incidence rate of whiplash injuries in Sweden is estimated to be 1.0-3.2/1000/year [1]. The injuries constitute a major health problem in Western society due to the large number of people with Whiplash associated disorder (WAD) and the high economical costs associated with WAD [2,3] People with acute WAD, mainly complain of neck-pain, stiffness, headache and dizziness. Other symptoms that may occur after the injury are fatigue, concentration and memory problems [2,4]. Most subjects with acute WAD are reported to recover within three months of the trauma [4] however, a significant number of persons experience symptoms several years

*Correspondence: brittmarie.stalnacke@rehabmed.umu.se

1 Department of Community Medicine and Rehabilitation (Rehabilitation Medicine) Bldg 9A, Umeå University Hospital, Umeå University, SE-901 85 Umeå, Sweden

Full list of author information is available at the end of the article after the accident $[1,5]$. Persistent neck-pain has been reported in $84-90 \%$ one to two year and in $55 \% 17$ years after the injury [6].

It is still unclear why pain and related symptoms do not resolve after the expected time of healing and which factors are involved in the persistence of symptoms and impairments after the trauma. A bio-psycho-social model is often used to describe the complex interaction of physical and psychological factors in the development of chronic WAD [7]. The long lasting problems after the injury may also interfere with occupational activities, the number of persons on sick-leave or unable to perform their ordinary duties six months after WAD have been reported to vary between 13 and 50\% [8,9]. In addition, chronic WAD may also affect leisure and daily life with social contacts and the total experience of life satisfaction [10]. 
Many studies of long-term problems after WAD have primarily focused on symptoms, especially neck pain in people seeking health care $[5,11]$ but fewer studies have investigated the long-term effects on activity/disability and life satisfaction. In addition, less is known about the differences between subjects who consider themselves as recovered and those who suffer from persistent disability. Sterling et al [12] investigated post-traumatic stress in relation to disability on the NDI during the first six months after whiplash injury. They found that persons who reported themselves to be recovered or to have mild disability six months post trauma reported decreased post-traumatic stress scores in comparison with early after the injury, whereas persons with moderate/severe disability reported persistent post-traumatic stress scores into the chronic stage.

In a scientific as well as in a clinical context, the need of studying subgroups of subjects has been proposed $[13,14]$. Information about the characteristics of these groups may provide help to develop adequate treatments. Since the levels of disability seems to be of importance in WAD, this study aimed to assess the difference in symptoms, psychological factors and life satisfaction between subjects who were classified as recovered and those who suffered from mild/severe disability based on the NDI $[12,15]$. In addition, this study examines whether the NDI is a clinically useful tool to classify whiplash disability.

\section{Methods}

A cross-sectional study design was used to study persons five years after whiplash injury. Using the Umeå University hospital's injury and trauma register, data was collected on subjects seeking acute medical assessment for whiplash trauma within three days after the trauma during 2001[16]. Exclusion criteria were fractures/dislocations of the cervical spine related to the injury and seeking medical care after three days. Questionnaires were sent to 304 persons injured during the year 2001 who were between 18 and 64 years old five years after the injury. Most questionnaires were answered by 191 persons; 25 persons actively declined from participating and 158 persons answered the NDI [15] (75 men, 83 women). Demographics, injury characteristics, pain intensity (VAS) [17], whiplash-related symptoms (Rivermead PostConcussion Symptoms Questionnaire RPQ) [18], depression (Beck Depression Inventory-II) [19], [20] post-traumatic stress (Impact of Event Scale) [21], life satisfaction (LiSat-11) [22], and some additional questions of pain locations and sick leave were related to the results of the NDI [15].

\section{Statistical analysis}

In accordance with the study by Sterling et al [12] the subjects were classified into three groups based on the NDI (recovered $\leq 8$, mild disability 10-28, moderate/ severe $\geq 30$ ). Data are reported as means with SD, unless indicated otherwise. Kruskal-Wallis and Mann-Whitney tests were used to test differences between groups (i.e. as post hoc tests). $\mathrm{X}^{2}$ test was used to analyse whether groups had different distributions. Multivariate logistic regression was performed to test associations between non-recovered and variables both from the background and five years after the injury $(1=$ non-recovered; mild and moderate/severe disability; and $0=$ recovered). The statistical significant level was set at $\mathrm{p}<0.01$ (two-tailed).

The study was approved by the ethics committee of Umeå University

\section{Results}

Based on results of the NDI: $34.8 \%(\mathrm{n}=55)$ were recovered, $37.3 \%(n=59)$ had mild disability and $27.3 \%(n=44)$ had moderate/severe disability $[12,15]$. No significant differences were found with respect to gender, age, cause of injury, or information from medical records or the injury and trauma register when comparing those who did not respond to the NDI $(n=33)$ to the 158 subjects.

\section{NDI and demographic/injury characteristics}

Somewhat higher proportions of women were found in the moderate/severe group (Table 1). The subjects in this group also had the lowest level of education. Only $50 \%$ in the moderate/severe group was working or studying five years after the injury and a majority of those on sick-leave related to the injury were found in this group.

\section{NDI and pain intensity}

The moderate/severe $(51.9 \pm 26.2 \mathrm{~mm})$ and the mild (19.1 $\pm 17.4 \mathrm{~mm}$ ) groups scored significantly higher on the VAS $(\mathrm{p}<0.001)$ than the recovered group $(3.6 \pm 7.8 \mathrm{~mm})$ and the moderate/severe group scored also significantly higher compared to the mild group $(\mathrm{p}<0.001)$.

\section{NDI and whiplash-related symptoms}

The frequency of occurrence of whiplash-related symptoms was assessed using the RPQ (Table 2). The total score of RPQ differed significantly between the three groups (moderate/severe: $31.9 \pm 13.3$, mild $15.55 \pm 10.9$, recovered: $3.78 \pm 4.6, \mathrm{p}<0.001$ ).

\section{$\mathrm{NDI}$ and depression}

The BDI-II was completed by 148 subjects (recovered $\mathrm{n}=$ 49 , mild $\mathrm{n}=57$, moderate/severe $\mathrm{n}=42$, (Table 3 )). The 
Table 1: Demographic and injury characteristics

\begin{tabular}{|c|c|c|c|c|}
\hline & $\begin{array}{l}\text { Recovered } \\
n=55(\%)\end{array}$ & $\begin{array}{l}\text { Mild } \\
n=59(\%)\end{array}$ & $\begin{array}{l}\text { Moderate/severe } \\
n=\mathbf{4 4}(\%)\end{array}$ & p-value \\
\hline Men & $28(50.9)$ & $29(49.0$ & $18(41.0)$ & \\
\hline Women & $27(49.1)$ & $30(51.0)$ & $26(59.0)$ & 0.581 \\
\hline Age, years, mean (SD) & $32.09(10.7)$ & $31.9(12.5)$ & $36.4(11.6)$ & 0.090 \\
\hline \multicolumn{5}{|l|}{ Education in years } \\
\hline 9 & $2(3.7)$ & $7(11.9)$ & $2(4.7)$ & \\
\hline $10-12$ & $23(42.6)$ & $31(52.5)$ & $27(62.8)$ & \\
\hline $13-21$ & 29(53.7) & $21(35.6)$ & 14(32.6) & 0.080 \\
\hline \multicolumn{5}{|c|}{ Occupational situation at time of injury } \\
\hline Working or student & $54(100)$ & $55(93.2)$ & $39(90.7)$ & \\
\hline Unemployed-seeking work & 0 & $1(1.7)$ & $1(2.3)$ & \\
\hline Sick-leave full or part time & 0 & $1(1.7)$ & $4(9.3)$ & \\
\hline Other & 0 & $2(3.4)$ & $3(6.7)$ & 0.091 \\
\hline \multicolumn{5}{|l|}{ Martial status } \\
\hline Married, cohabitating & $40(74.1)$ & $40(67.8)$ & $26(60.5)$ & \\
\hline Single, divorced or widowed & $13(24.1)$ & $15(25.4)$ & 16(37.2) & \\
\hline Living with parents & $1(1.9)$ & $4(6.8)$ & $1(2.3)$ & 0.341 \\
\hline Vehicle accidents & $43(78.2)$ & $51(86.4)$ & $31(70.5)$ & 0.139 \\
\hline \multicolumn{5}{|l|}{ Position in vehicle: } \\
\hline Driver & $36(83.7)$ & $38(74.5)$ & $23(74.2)$ & \\
\hline Passenger front & $4(9.3)$ & $7(13.7)$ & $6(19.4)$ & \\
\hline Passenger back & $2(4.7)$ & $3(5.9)$ & $1(3.2)$ & \\
\hline Buss passenger & $1(2.3)$ & $2(3.9)$ & 0 & \\
\hline Passenger unknown & 0 & $1(2.0)$ & $1(3.2)$ & 0.146 \\
\hline \multicolumn{5}{|l|}{ Seat belt } \\
\hline yes & $35(81.4)$ & $39(76.5)$ & $25(80.6)$ & \\
\hline no & $3(7.0)$ & $5(9.8)$ & $2(6.5)$ & \\
\hline not applicable & $2(4.6)$ & $6(11.7)$ & $1(3.2)$ & \\
\hline unknown & $3(7.0)$ & $1(2.0)$ & $3(9.7)$ & 0.512 \\
\hline \multicolumn{5}{|c|}{ Occupational situation at time of follow-up $n=157$} \\
\hline Working/Student & $54(98.2)$ & $55(93.2)$ & $22(50.0)$ & \\
\hline Unemployed-seeking work & 0 & $1(1.7)$ & $1(2.3)$ & \\
\hline Sick-leave full or part time & 0 & $1(1.7)$ & $21(47.7)$ & \\
\hline Other & 0 & $2(3.4)$ & 0 & $<0.001$ \\
\hline \multicolumn{5}{|l|}{ Injury reported to insurance company } \\
\hline yes & $21(38.9)$ & $26(44.1)$ & $30(69.8)$ & \\
\hline no & $24(44.4)$ & $16(27.1)$ & $6(14.0)$ & \\
\hline don't know & $9(16.7)$ & $17(28.8)$ & $7(16.3)$ & 0.004 \\
\hline
\end{tabular}


Table 2: Frequency of occurrence of whiplash-related symptoms

\begin{tabular}{|c|c|c|c|c|c|c|c|}
\hline \multirow[t]{2}{*}{ Rivermead Post-Concussion Symptoms Questionnaire } & \multicolumn{2}{|c|}{ Recovered } & \multicolumn{2}{|l|}{ Mild } & \multicolumn{2}{|c|}{ Moderate/Severe } & \multirow[b]{2}{*}{ p-value } \\
\hline & $\mathbf{n}=\mathbf{5 5}$ & $\%$ & $\mathbf{n}=\mathbf{5 9}$ & $\%$ & $n=44$ & $\%$ & \\
\hline Dizziness & 10 & 10.9 & 22 & 37.9 & 35 & 79.5 & $<0.001$ \\
\hline Nausea/vomiting & 3 & 5.5 & 14 & 24.1 & 23 & 52.3 & $<0.001$ \\
\hline Sleep disturbance & 8 & 14.5 & 30 & 51.7 & 36 & 81.8 & $<0.001$ \\
\hline Fatigue & 15 & 27.3 & 38 & 65.5 & 41 & 93.2 & $<0.001$ \\
\hline Irritability & 9 & 16.4 & 36 & 62.1 & 42 & 95.5 & $<0.001$ \\
\hline Feeling depressed & 9 & 16.4 & 24 & 41.4 & 35 & 79.5 & $<0.001$ \\
\hline Feeling frustrated & 11 & 20.0 & 28 & 48.3 & 36 & 81.8 & $<0.001$ \\
\hline Poor memory & 13 & 23.6 & 38 & 65.5 & 39 & 88.6 & $<0.001$ \\
\hline Poor concentration & 11 & 20.0 & 35 & 60.3 & 41 & 93.2 & $<0.001$ \\
\hline Noise sensitivity & 5 & 9.1 & 28 & 48.3 & 31 & 70.5 & $<0.001$ \\
\hline Blurred vision & 6 & 10.9 & 20 & 34.5 & 27 & 61.4 & $<0.001$ \\
\hline Sensitivity to light & 11 & 20.0 & 27 & 46.6 & 35 & 79.5 & $<0.001$ \\
\hline Double vision & 1 & 1.8 & 8 & 13.8 & 16 & 36.4 & $<0.001$ \\
\hline Restlessness & 13 & 23.6 & 29 & 50.0 & 29 & 65.9 & $<0.001$ \\
\hline Taking longer to think & 10 & 18.2 & 27 & 46.6 & 39 & 88.6 & $<0.001$ \\
\hline Headache & 10 & 18.2 & 31 & 53.4 & 40 & 90.1 & $<0.001$ \\
\hline Total score, mean (SD) & $3.8(4.6)$ & 15.6 & $(10.9)$ & 31.9 & (13.3) & & $<0.001$ \\
\hline \multicolumn{8}{|l|}{ Pain regions } \\
\hline Neck pain & 14 & 25.9 & 43 & 74.1 & 43 & 97.7 & $<0.001$ \\
\hline Upper back pain & 15 & 27.8 & 39 & 69.6 & 38 & 86.4 & $<0.001$ \\
\hline Lower back pain & 15 & 27.8 & 29 & 53.7 & 35 & 79.5 & $<0.001$ \\
\hline
\end{tabular}

recovered and the mild NDI-groups scored significantly lower on the BDI-II (recovered group $(2.9 \pm 4.4$, mild: 6.7 \pm 6.3 ) compared to the moderate/severe: $18.2 \pm 9.4 ; \mathrm{p}<$ $0.001)$. The BDI-scores of the recovered group compared with the mild group was also significant $(\mathrm{p}<0.001)$. Severe depression level was reported by $11.9 \%$ of the moderate/severe group.

\section{NDI and post-traumatic stress}

Table 4 shows differences between the groups on the IES. Post-hoc comparisons showed significant differences between the moderate/severe and the recovered group ( $\mathrm{p}$ $<0.001$ ) on the total IES score and the subscales Intrusion and Avoidance. When comparing the recovered and the mild groups, there were significant differences on the total IES score $(\mathrm{p}=0.019)$ and the Intrusion subscale $(\mathrm{p}=$ $0.008)$. No difference was found on the Avoidance subscale $(\mathrm{p}=0.119)$.

\section{NDI and life Satisfaction}

The percentage of satisfied on the separate domains [22] are shown in Table 5. (Higher scores on the LiSat-11 indi- cate higher life satisfaction.) The recovered group scored significantly higher than the mild group on one of the eleven domains; the recovered group scored significantly higher than the moderate/severe group on eight domains. Significant differences were found between the moderate/severe and the mild groups for five of the eleven domains. There were no differences between any of the three groups on the domains contact with friends, family life, partner relationship and sexual life.

\section{Multivariate regression}

The significant variables in a univariate analysis (age, RPQ-symptoms, some LiSat-11 domains, depression, and post-traumatic stress) were analysed in a stepwise multivariate logistic regression model that showed a statistically significant association only between non-recovered and depression $(\mathrm{OR}=1.258, \mathrm{CI}$ : $1.166-1.356)$.

\section{Discussion}

Although previous studies have investigated disability in whiplash patients [23,24], to our knowledge this study is the first to investigate differences in pain intensity, symp- 
Table 3: Beck depression inventory (BDI-II)

\begin{tabular}{|c|c|c|c|c|}
\hline Level of depression & $\begin{array}{l}\text { All subjects } \\
(n=148)\end{array}$ & $\begin{array}{l}\text { Recovered (R) } \\
(n=49)\end{array}$ & $\begin{array}{l}\text { Mild (M) } \\
(\mathrm{n}=57)\end{array}$ & $\begin{array}{l}\text { Moderate/Severe (MS) } \\
(n=42)\end{array}$ \\
\hline Minimal & 110 & 46 & 49 & 15 \\
\hline n (\%) & $(74.3)$ & $(93.9)$ & $(86.0)$ & $(35.7)$ \\
\hline Mild & 21 & 3 & 4 & 14 \\
\hline n (\%) & $(14.2)$ & (6.1) & $(7.0)$ & (33.3) \\
\hline Moderate & 12 & - & 4 & 8 \\
\hline n (\%) & $(8.1)$ & & $(7.0)$ & $(19.0)$ \\
\hline Severe & 5 & - & & 5 \\
\hline$(n \%)$ & (3.4) & & & (11.9) \\
\hline Total score & 8.69 & 2.86 & 6.72 & 18.2 \\
\hline Mean (SD) & $(9.18)$ & $(4.35)$ & $(6.29)$ & $(9.39)$ \\
\hline \multirow[t]{2}{*}{ P-value } & & R vs $\mathrm{M}:$ & M vs MS: & MS vs R: \\
\hline & & $<0.001$ & $<0.001$ & $<0.001$ \\
\hline
\end{tabular}

toms, post-traumatic stress, depression, and life satisfaction between subjects with persistent disability and subjects classified as recovered in a "non-help-seeking" population long time after whiplash injury.

In the present study the NDI was used to assess and to classify disability in according to a previous study [12]. In their study of whiplash patients six months post trauma, the NDI-scores were slightly lower in comparison with the three subgroups in the present study. Regardless of the time difference between the two studies, it seems possible to assume that the character of disability in persons with WAD around half a year after the injury may persist for longer time. The results on the NDI in our study also agree with the scores reported three years [24] and 17 years [23] after the injury.

In accordance with previous studies of WAD [5], neck pain was the most commonly reported symptom in the moderate/severe and the mild groups. These frequencies were close to results (55\%) reported 17 years after the injury [23]. However, pain was also reported in the recovered group, but the frequencies of pain locations (neck, upper and lower back pain) were more equal. Among the whiplash-related symptoms, cognitive deficits with poor concentration and poor memory were unexpectedly high both in the recovered group (25\%) and in the moderate/ severe and mild groups (60-93\%). Since chronic pain [25], depression and post-traumatic stress [26] may affect cognitive symptoms, these factors might have contributed to the cognitive disturbances in all groups in the present study.

The highest post-traumatic stress scores were reported in the moderate/severe group and the frequency of distinct post-traumatic stress reaction (36.3\%) was clearly higher than reported in whiplash patients early after injury (13\%) [27]. Some evidence for an association between greater post-traumatic stress and late whiplash syndrome [28] has been shown. However, since the levels of post-traumatic stress were high especially in the moderate/severe group, these findings may support the recommendation of early diagnoses and treatment of acute stress to minimize the risk for long-lasting symptoms [29].

Chronic WAD may have a negative impact on quality of life [10]. When comparing life satisfaction on the LiSat-11 between the three disability groups in our study with a large population-based Swedish reference group (2533 subjects) [22], the mild and moderate/severe groups showed lower levels of life satisfaction. However, significant differences were found between the moderate/severe group and the recovered group in eight of eleven domains. Previous research has shown that depression influences outcome for quality of life in chronic WAD 
Table 4: Impact of event scale

\begin{tabular}{|c|c|c|c|c|}
\hline Level of stress reaction & $\begin{array}{l}\text { Recovered (R) } \\
(n=54)\end{array}$ & $\begin{array}{l}\text { Mild (M) } \\
(\mathrm{n}=59)\end{array}$ & $\begin{array}{l}\text { Moderate/Severe (MS) } \\
(n=44)\end{array}$ & P-value \\
\hline Sub clinical (0-8) & 42 & 37 & 12 & \\
\hline $\mathrm{n} \%$ & $77.8 \%$ & $67.7 \%$ & $27.3 \%$ & \\
\hline Mild (9-25) & 10 & 13 & 16 & \\
\hline $\mathrm{n} \%$ & $18.5 \%$ & $22.0 \%$ & $36.4 \%$ & \\
\hline Moderate (26-43) & 2 & 8 & 10 & \\
\hline $\mathrm{n} \%$ & $3.7 \%$ & $13.6 \%$ & $22.7 \%$ & \\
\hline Severe (44-75) & - & 1 & 6 & \\
\hline $\mathrm{n} \%$ & & $1.7 \%$ & $13.6 \%$ & \\
\hline Total score & 4.91 & 10.15 & 21.91 & $<0.001$ \\
\hline Mean (SD) & $(7.06)$ & (12.39) & $(16.87)$ & \\
\hline Intrusion subscale & 2.35 & 5.03 & 10.93 & $<0.001$ \\
\hline Mean (SD) & $(3.74)$ & $(6.08)$ & $(8.81)$ & \\
\hline Avoidance subscale & 2.59 & 5.12 & 10.98 & $<0.001$ \\
\hline Mean (SD) & $(4.02)$ & (7.68) & $(9.11)$ & \\
\hline
\end{tabular}

[30] and the significantly higher BDI scores in the moderate/severe group may have contributed to their low life satisfaction. Moreover, the association between depression and non-recovered in the multivariate analysis indicates the importance of assessment and treatment of depression in WAD-patients.

Some objections may be raised concerning the findings of this study. Since the variables were investigated in subjects five years after the injury, one cannot rule out that systematic distortions as well as other factors might have influenced the results. Moreover, the subjects in the present study were divided into three disability subgroups based on the NDI. However, as we had no information about the previous levels of disability, there might have been high disability levels in the moderate/severe group before the injury. Although the recovered group also reported presence of symptoms, this might be a result of good coping strategies. Unfortunately, no questionnaires about coping or catastrophic thoughts were included in the study and there was no information about rehabilitation and medication. Fewer people answered the NDI than other questionnaires; a probable reason might be that the NDI was the last questionnaire in a set of several instruments.

\section{Conclusion}

This study has implications for clinicians. Although symptoms often are reported after whiplash injury, the activity levels may differ. Due to the complexity of WAD, the importance of identifying subgroups of WAD has been proposed in order to better tailor their treatment $[13,14]$. In a previous study, NDI was found to be the most sensitive instrument among several questionnaires to predict poor outcome [24]. Our study adds to previous research: the NDI seems to be a useful instrument for classifying whiplash subjects into subgroups. In general, we found that the group with moderate/severe disability reported high frequency of symptoms, high depression and post-traumatic stress scores and low level of life satisfaction. However, the recovered group also reported symptoms and post-traumatic stress scores, but these levels were not related to disability. 
Table 5: LiSat-11

\begin{tabular}{|c|c|c|c|c|c|}
\hline Life Satisfaction & $\begin{array}{c}\text { Recovered (R) } \\
\text { Mean (SD) }\end{array}$ & $\begin{array}{c}\text { Mild (M) } \\
\text { Mean (SD) }\end{array}$ & $\begin{array}{c}\text { Moderate/Severe (MS) } \\
\text { Mean (SD) }\end{array}$ & R/M/MS & P-value \\
\hline Life as a whole & $4.92(0.93)$ & $4.66(0.81)$ & $3.75(1.12)$ & R vs M: & ns \\
\hline \multirow[t]{2}{*}{ Satisfied \% } & $71 \%$ & $59 \%$ & $23 \%$ & R vs MS: & $p<0.001$ \\
\hline & & & & M vs MS: & $p<0.001$ \\
\hline Vocation & $4.67(1.04)$ & $4.20(1.19)$ & $2.93(1.65)$ & R vs M: & ns \\
\hline \multirow[t]{2}{*}{ Satisfied \% } & $65 \%$ & $42 \%$ & $23 \%$ & R vs MS: & $p<0.001$ \\
\hline & & & & M vs MS: & $p<0.001$ \\
\hline Economy & $4.35(1.08)$ & $3.86(1.20)$ & $3.16(1.54)$ & R vs M: & ns \\
\hline \multirow[t]{2}{*}{ Satisfied \% } & $44 \%$ & $27 \%$ & $14 \%$ & R vs MS: & $p<0.001$ \\
\hline & & & & M vs MS: & ns \\
\hline Leisure & $4.52(1.04)$ & $4.07(1.34)$ & $3.48(1.49)$ & R vs M: & ns \\
\hline \multirow[t]{2}{*}{ Satisfied \% } & $46 \%$ & $42 \%$ & $26 \%$ & R vs MS: & $p<0.001$ \\
\hline & & & & M vs MS: & ns \\
\hline Contacts & $4.71(0.98)$ & $4.53(1.15)$ & $4.07(1.21)$ & R vs M: & ns \\
\hline \multirow[t]{2}{*}{ Satisfied \% } & $58 \%$ & $58 \%$ & $42 \%$ & R vs MS: & $p<0.001$ \\
\hline & & & & M vs MS: & ns \\
\hline Sexual life & $4.47(1.33)$ & $4.08(1.63)$ & $3.67(1.58)$ & R vs M: & ns \\
\hline \multirow[t]{2}{*}{ Satisfied \% } & $58 \%$ & $50 \%$ & $33 \%$ & R vs MS: & ns \\
\hline & & & & M vs MS: & ns \\
\hline$A D L$ & $5.83(0.47)$ & $5.61(0.83)$ & $4.68(1.43)$ & R vs M: & ns \\
\hline \multirow[t]{2}{*}{ Satisfied \% } & $96 \%$ & $93 \%$ & $61 \%$ & R vs MS: & $p<0.001$ \\
\hline & & & & M vs MS: & $p<0.001$ \\
\hline Family life & $5.39(0.62)$ & $5.23(0.87)$ & $4.92(1.23)$ & R vs M: & ns \\
\hline \multirow[t]{2}{*}{ Satisfied \% } & $94 \%$ & $81 \%$ & $70 \%$ & R vs MS: & ns \\
\hline & & & & M vs MS: & ns \\
\hline Partner relationship & $5.40(0.78)$ & $5.21(1.02)$ & $4.88(1.34)$ & R vs M: & ns \\
\hline \multirow[t]{2}{*}{ Satisfied \% } & $87 \%$ & $81 \%$ & $67 \%$ & R vs MS: & ns \\
\hline & & & & M vs MS: & ns \\
\hline Somatic health & $4.78(1.03)$ & $4.02(1.19)$ & $2.32(1.16)$ & R vs M: & $\mathrm{p}<0.001$ \\
\hline \multirow[t]{2}{*}{ Satisfied \% } & $65 \%$ & $32 \%$ & $5 \%$ & R vs MS: & $p<0.001$ \\
\hline & & & & M vs MS: & $\mathrm{p}<0.001$ \\
\hline Psychological health & $5.18(0.86)$ & $4.75(0.99)$ & $3.77(1.25)$ & R vs M: & ns \\
\hline \multirow[t]{2}{*}{ Satisfied \% } & $78 \%$ & $59 \%$ & $30 \%$ & R vs MS: & $p<0.001$ \\
\hline & & & & M vs MS: & $p<0.001$ \\
\hline
\end{tabular}




\section{Competing interests}

The authors declare that they have no competing interests.

\section{Authors' contributions}

BMS designed the study. Both authors contributed to the data analyses and to writing of the manuscript.

\section{Acknowledgements}

The study was supported by the Swedish Association of Survivors of Traffic Accidents and the Polio Cancer and Traffic Injury Fund.

\section{Author Details}

Department of Community Medicine and Rehabilitation (Rehabilitation Medicine) Bldg 9A, Umeå University Hospital, Umeå University, SE-901 85 Umeå, Sweden

Received: 11 January 2010 Accepted: 13 July 2010

Published: 13 July 2010

\section{References}

1. Sterner Y, Toolanen G, Gerdle B, Hildingsson C: The incidence of whiplash trauma and the effects of different factors on recovery. J Spinal Disord Tech 2003, 16(2):195-199.

2. Spitzer WO, Skovron ML, Salmi LR, Cassidy JD, Duranceau J, Suissa S, et al:: Scientific monograph of the Quebec Task Force on WhiplashAssociated Disorders: redefining "whiplash" and its management. Spine 1995, 20(8 Suppl):1S-73S.

3. Bylund PO, Bjornstig U: Sick leave and disability pension among passenger car occupants injured in urban traffic. Spine 1998, 23(9):1023-1028.

4. Hildingsson C, Toolanen G: Outcome after soft-tissue injury of the cervical spine. A prospective study of 93 car-accident victims. Acta Orthop Scand 1990, 61(4):357-359.

5. Haldorsen T, Waterloo K, Dahl A, Mellgren SI, Davidsen PE, Molin PK: Symptoms and cognitive dysfunction in patients with the late whiplash syndrome. App/ Neuropsychol 2003, 10(3):170-175.

6. Kyhlback M, Thierfelder T, Soderlund A: Prognostic factors in whiplashassociated disorders. Int J Rehabil Res 2002, 25(3):181-187.

7. Gatchel RJ, Peng YB, Peters ML, Fuchs PN, Turk DC: The biopsychosocial approach to chronic pain: scientific advances and future directions. Psychol Bull 2007, 133(4):581-624.

8. Gargan MF, Bannister GC: The rate of recovery following whiplash injury. Eur Spine J 1994, 3(3):162-164.

9. Harder S, Veilleux M, Suissa S: The effect of socio-demographic and crash-related factors on the prognosis of whiplash. J Clin Epidemiol 1998, 51(5):377-384

10. Peolsson M, Borsbo B, Gerdle B: Generalized pain is associated with more negative consequences than local or regional pain: a study of chronic whiplash-associated disorders. J Rehabil Med 2007, 39(3):260-268.

11. Norris $\mathrm{SH}$, Watt I: The prognosis of neck injuries resulting from rear-end vehicle collisions. J Bone Joint Surg Br 1983, 65(5):608-611.

12. Sterling $M$, Kenardy J, Jull G, Vicenzino B: The development of psychological changes following whiplash injury. Pain 2003, 106(3):481-489.

13. Turk DC: The potential of treatment matching for subgroups of patients with chronic pain: lumping versus splitting. Clin J Pain 2005, 21(1):44-55. discussion 69-72

14. Soderlund A, Denison E: Classification of patients with whiplash associated disorders (WAD): reliable and valid subgroups based on the Multidimensional Pain Inventory (MPI-S). Eur J Pain 2006, 10(2):113-119.

15. Vernon $\mathrm{H}$, Mior S: The Neck Disability Index: a study of reliability and validity. J Manipulative Physiol Ther. 1991, 14(7):409-415.

16. Stålnacke BM: Relationship between symptoms and psychological factors five years after whiplash injury. J Rehabil Med 2009, 41(5):353-359.

17. Price DD, Bush FM, Long S, Harkins SW: A comparison of pain measurement characteristics of mechanical visual analogue and simple numerical rating scales. Pain 1994, 56(2):217-226.

18. King NS, Crawford S, Wenden FJ, Moss NE, Wade DT: The Rivermead Post Concussion Symptoms Questionnaire: a measure of symptoms commonly experienced after head injury and its reliability. I Neurol 1995, 242(9):587-592.

19. Beck AT, Ward CH, Mendelson M, Mock J, Erbaugh J: An inventory for measuring depression. Arch Gen Psychiatry 1961, 4:561-571.

20. Beck AT, Steer RA, Brown GK: Beck Depression Inventory- Second Edition Manual, Swedish version. Sandviken: Psykologiförlaget; 2005.

21. Horowitz M, Wilner N, Alvarez W: Impact of Event Scale: a measure of subjective stress. Psychosom Med 1979, 41(3):209-218.

22. Fugl-Meyer AR, Melin R, Fugl-Meyer KS: Life satisfaction in 18- to 64-yearold Swedes: in relation to gender, age, partner and immigrant status. J Rehabil Med 2002, 34(5):239-246.

23. Bunketorp L, Stener-Victorin E, Carlsson J: Neck pain and disability following motor vehicle accidents--a cohort study. Eur Spine J 2005, 14(1):84-89.

24. Miettinen T, Leino $\mathrm{E}$, Airaksinen O, Lindgren KA: The possibility to use simple validated questionnaires to predict long-term health problems after whiplash injury. Spine 2004, 29(3):E47-51.

25. Radanov BP, Bicik I, Dvorak J, Antinnes J, von Schulthess GK, Buck A: Relation between neuropsychological and neuroimaging findings in patients with late whiplash syndrome. J Neurol Neurosurg Psychiatry 1999, 66(4):485-489

26. Twamley EW, Hami S, Stein MB: Neuropsychological function in college students with and without posttraumatic stress disorder. Psychiatry Res 2004, 126(3):265-274.

27. Kongsted A, Bendix T, Qerama E, Kasch H, Bach FW, Korsholm L, et al:: Acute stress response and recovery after whiplash injuries. A one-year prospective study. Eur J Pain 2008, 12(4):455-463.

28. Williamson E, Williams M, Gates S, Lamb SE: A systematic literature review of psychological factors and the development of late whiplash syndrome. Pain 2008, 135(1-2):20-30.

29. Jansen GB, Edlund C, Grane P. Hildingsson C, Karlberg M, Link H, et al: Whiplash injuries: diagnosis and early management. In Eur Spine $J$ Volume 17. Issue Suppl 3 The Swedish Society of Medicine and the Whiplash Commission Medical Task Force; 2008:S355-417.

30. Borsbo B, Peolsson M, Gerdle B: Catastrophizing, depression, and pain: correlation with and influence on quality of life and health - a study of chronic whiplash-associated disorders. J Rehabil Med 2008, 40(7):562-569.

doi: 10.1186/1756-0500-3-190

Cite this article as: Merrick and Stålnacke, Five years post whiplash injury: Symptoms and psychological factors in recovered versus non-recovered BMC Research Notes 2010, 3:190

\section{Submit your next manuscript to BioMed Centra and take full advantage of:}

- Convenient online submission

- Thorough peer review

- No space constraints or color figure charges

- Immediate publication on acceptance

- Inclusion in PubMed, CAS, Scopus and Google Scholar

- Research which is freely available for redistribution 